\title{
Cultural Markedness and Strategies for Translating Idiomatic Expressions in the Epic Poem "The Mountain Wreath" into English
}

\begin{abstract}
Jelena Vulanović
Doi:10.5901/mjss.2014.v5n13p210

University of Montenegro, Faculty of Philosophy, Nikšić

\section{Abstract}

This paper focuses on the types of translation strategies used in rendering idiomatic expressions found in the epic poem 'The Mountain Wreath' into English. It seeks to explore their representation and frequency of usage, as well as the extent to which the choice of the strategy depends on cultural markedness of idiomatic units. The research is done based on the Baker's translation model, which is for the purposes of the present study modified to include two additional strategies - apart from the standard ones, i.e. using an idiom of similar meaning and form, using an idiom of similar meaning but dissimilar form, translation by paraphrase, and translation by omission, it also incorporates loan translation (calque) and single word matches. Upon conducting both qualitative and quantitative analysis it has been concluded that loan translation and single word matches/translation by omission were the most and the least common strategies, with the frequencies of $31.94 \%$ and $1.39 \%$, respectively. Results also suggest that the application of translation strategies involving use of idioms appears to be mostly restricted to the items expressing universal as opposed to culture-specific concepts. On the basis of these findings the paper argues that cultural markedness of idiomatic expressions could be considered as one of the most important factors behind the choice of translation strategies.
\end{abstract}

Keywords: idioms, idiomatic expressions (units), translation of idioms, translation strategies, cultural markedness.

\section{Introduction}

Translation is a work that takes a text and transposes it into another culture." Susan Bassnet (1991)

The process of rendering idiomatic expressions into another language is considered to be one of the most difficult tasks and major challenges in translation. The difficulty of finding adequate inter-lingual idiomatic pairs arises from the fact that idiomatic expressions often carry certain stylistic, expressive and cultural connotations that are not easily transferred between languages. In other words, finding the exact semantic equivalents is difficult for manifold reasons: it involves rendering all of the various aspects of idiomatic meaning into the target language. Yet, however diverse the problems inherent in translation of idioms may be, they could be classified into two major categories: the problems related to identification and the problems related to the choice of equivalents. It goes without saying that neither of these problems could be handled without having profound knowledge of the languages involved. Apart from linguistic knowledge, a translator should also have the knowledge of extra-linguistic context given the fact that majority of idioms are culturespecific and inextricably linked to the history, customs, rites and beliefs of a certain community. It is precisely that cultural markedness or "peculiarity" that makes idioms difficult to translate, or even untranslatable at times. As Schwarz (2003) points out, "although more and more concepts are shared and understood between different cultures, there are still many terms and expressions which reflect the morals and values of a particular culture and have no true equivalent in $\mathrm{TL}$ (target language) [...] and to deal with these cultural terms successfully a translator has to be not only bilingual, but also bi-cultural." (p.1)

In regards to a lack of idiomatic equivalence in general, Mona Baker (1992) writes that "different languages express meanings using different linguistic means such as fixed expressions, idioms, words, etc and it is very hard to find an equivalent of the same meaning and form in the target language" (p.68). Yet, the degree of equivalence between idioms in SL (source language) and TL (target language) varies depending on the type of relationship between the languages: the more genetically distant the two languages and the more different the cultural context and conventions they reflect, the lesser the degree of idiomatic equivalence. Different types of equivalence between idioms in SL and TL, according to Gläser (as cited in Valero-Garcés, 1997), include:
1. Total equivalence
2. Partial equivalence
3. Non-equivalence 
4. Apparent equivalence ("false friends") (p. 36).

In the same vein, Mona Baker (1992) distinguishes between the following categories/degrees of equivalence:

1. An idiom or fixed expression may have no equivalent in the target language.

2. An idiom or fixed expression may have a similar counterpart in the target language, but its context of use may be different.

3. An idiom may be used in the source text in both its literal and idiomatic senses at the same time.

4. The very convention of using idioms in written discourse, the contexts in which they can be used, and their frequency of use may be different in the source and target languages. (p. 65-71)

By establishing these categories of equivalence, Baker (1992) also points out to various factors that should be taken into consideration while translating idioms: appropriateness in a certain context, differences in denotative and connotative meanings, frequency of usage etc. As Valero-Garcés (1997) puts it "it is not only a question of whether an idiom with similar meaning is available in the TL; other factors include the way in which the idiom constituents may be manipulated in the ST, or the appropriateness or inappropriateness of using idioms in a given register in the TL, as well as the content and receptor of the TT." (p. 36)

\section{Defining Idioms: Theoretical Issues}

"Phraseology is a field bedeviled by the proliferation of terms and by the conflicting uses of the same term." Cowie (1998, p. 210)

Despite the increasing amount of research and a substantial body of work amassed in the field of phraseology during the past half-century, no consensus has yet emerged concerning its terminology, definitions and scope. Due to this lack of consensus there is a multitude of terms used to refer to the basic unit of phraseology: phraseological units (Ginzburg et al. 1979, Gläser, 1986) phraseologisms (Gries, 2008 ) word combinations Cowie, 1998), phrasal lexemes (Lipka 1991, Moon 1998) multi-word expressions and idioms (Fernando 1996), idioms (Altenberg 1998), prefabricated patterns (Granger 1998), fixed expressions (Alexander 1978, Fillmore \& Atkins 1994), phraseological collocations and structural frames (Moon 1998), formulaic sequence (Wray 1999), multiword units (Fellbaum 2007). In this paper we will use the term idiom/idiomatic expression to refer to conventionalized, expressive multiword units whose meaning is different from the meaning conveyed by their constituents. As for the definitions, some of the most widely cited are the following:

"idioms are frozen patterns of language which allow little or no variation in form and often carry meanings which can not be deduced from their individual components". (Baker, 1992, p.63)

"we can say that an idiom is a number of words which [when they are] taken together, mean something different from the individual words of the idiom when they stand alone". (McMordiew, 1983, p. 4)

"an idiom is a term used in grammar and lexicology to refer to a sequence of words which are semantically or syntactically restricted, so that they function as a single unit. From a semantic viewpoint, the meaning of the individual words cannot be summed to produce the meaning of the idiomatic expression as a whole. From a syntactic viewpoint, the words do not often permit the usual variability they display in other contexts ..." (Crystal, 1991, p. 170)

Stressing the need for a clear-cut and generally agreed-upon definition, Gries (2008) tries to identify crucial dimensions/defining parameters of idiomatic expressions (to which he refers as phraseologisms):

(i) the nature of the elements involved in a phraseologism;

(ii) the number of elements involved in a phraseologism;

(iii) the number of times an expression must be observed before it counts as a phraseologism;

(iv) the permissible distance between the elements involved in a phraseologism;

(v) the degree of lexical and syntactic flexibility of the elements involved;

(vi) the role that semantic unity and semantic non-compositionality / non-predictability play in the definition. (Gries, 2008, p.4)

According to given criteria, he defines a phraseologism "as the co-occurrence of a form or a lemma of a lexical item and one or more additional linguistic elements of various kinds which functions as one semantic unit in a clause or sentence and whose frequency of co-occurrence is larger than expected on the basis of chance". (Gries, 2008, p.5)

\section{Idiom Translation Strategies}


Having discussed the major areas of difficulties related to idiomatic translation, we will now focus on the problem-solving mechanisms/strategies as suggested by Mona Baker (1992). In her book "In other words", she identifies four categories of translation strategies:

1) Using an idiom of similar meaning and form

2) Using an idiom of similar meaning but dissimilar form

3) Translation by paraphrase

4) Translation by omission (Baker, 1992, pp. 71-78).

The first strategy proposed by Baker involves the use of idiomatic counterparts in TL that match the SL expressions both in meaning and in form. In other words, these inter-lingual idiomatic pairs, often called "the equivalents" in Russian linguistics, have similar denotative and connotative meanings: Montenegrin: svijetlo na kraju tunela English: (the) light at the end of the tunnel

The second strategy differs from the first one according to the degree of equivalence between the inter-lingual idiomatic pairs. In this case idioms have the same (or similar) connotative meaning but they are comprised of different lexical elements and are also referred to as "the analogues": Montenegrin: nositi drva u šumu English: carry coals to Newcastle

The third strategy- translation by paraphrase is usually applied when no appropriate idiomatic equivalent can be found in the TL. Idioms are therefore not rendered into TL as idioms, but semantic equivalence is still reached: Montenegrin: držati se čega kao pijan plota (literally translated: to hold onto something as a drunken man holds onto the fence) English: to keep insisting on something

As it is clear from its name, the last strategy implies omission of idiomatic units from the text in the TL. According to Baker (1992) it is only acceptable if there is "no close match in the target language, the meaning cannot be paraphrased or for stylistic reasons" (p.77). However, she thinks that this should be translator's "last resort" and that such omission should be compensated by inserting idioms elsewhere in the text "to make up for any loss of meaning, emotional force or stylistic effect which may not be possible to produce directly at a given point in the target text" (Baker, 1992, p.78).

For the purposes of the present study Baker's translation model was modified to include two additional strategies loan translation (calque) and single word matches. Upon analyzing translation equivalents of IE (idiomatic expressions) found in the poem, we noticed how translators often chose to keep as close to the original text as possible, producing numerous calques in the process (see examples (5), (7), etc.). The other strategy simply reflects the fact that the same concept could be expressed by idiomatic unit in the one and lexical unit in the other language: Montenegrin: zapaliti English: set on fire

\section{4. "The Mountain Wreath" and the Analysis of Translation Strategies Applied}

The analytical part of this paper is based on the epic poem "The Mountain Wreath" and the translations into English made by James Wiles, Vasa Mihailović and Dane Mrkić. In order to gain a better insight into the structure of translation equivalents and the respective strategies applied, we will classify idiomatic expressions found in the poem into four categories according to formal and semantic criteria. This in turn will enable us to examine the differences between the categories, i.e. to ascertain whether and to what extent the choice of translation strategies depends on the semantic and grammatical makeup of idiomatic expressions. Present typology of IE found in the poem includes the following categories:
1. (pure) idioms;
2. idiomatic similes;
3. proverbs and sayings;
4. locutions.

\section{1 (Pure) idioms}

Results obtained within the category of pure idioms indicate that there are two main factors influencing the choice of translation strategies : cultural markedeness as opposed to "universal character" and the degree of semantic opacity. The IE of universal character - originating from the Bible, classical languages or literature etc. and thus present in majority of languages, were rendered into TL as idioms (mostly of similar meaning and similar form):

(1) Krst nositi vama je suđeno (TMW: 2348) /Your destiny is to bear the Cross (Mihailović: 2448)/ It is your lot and call to bear the Cross (Wiles :2466)/ To bear the Cross is your destiny. (Mrkić: 2348)

As opposed to that, there were no instances of idiom-to-idiom translation found for culture-specific idioms. Such idioms 
were mostly translated word-for-word - literally (2) /calquing (3) or by paraphrase (5):

(2) zmaja ljuta1 (TMW:573) /bitter dragon(Mrkić: 573)/fierce dragon(Mihailović:611)/ferocious dragon (Wiles:613)

(3) Prosta sablja po sto puta Turska; od Kosova2 koja nas siječe (TMW: 2096)/ A hundred pardons on the Turkish sabre; Which has been slaying us since Kosovo (Mrkić: 2095)/ But hundred pardons e'en to Turkish swords -Harvest enough from Kossovo they've reaped! (Wiles: 2210)/ It's easier to bear the Turkish sword - since Kosovo our reaper and killer (Mihailović: 2195)

There is also a case of a single word match:

(4) ljute nevolje (TMW:1464) /bitter agony (Mrkić:1464)/ dreadful misery (Mihailović:1505)/ lamentations (Wiles:1526) Idioms that are both culture-specific and semantically opaque were translated either literally or by paraphrase. Instances of literal translation of idioms with similar counterparts in $T L$ (in this case expression go through the mill ) indicate that the problems often stem from translator's inability to identify IE:

(5) Ja sam proša sito i rešeto (TMW: 2486)/ I have passed through both sieve and colander (Mihailović: 2590) / Through sieve l've passed and colander (Wiles: 2623)/I have passed through sieve and colander (Mrkić: 248)

On the other hand, translation by paraphrase points to either lack of idiomatic equivalence or to problems with finding/using the corresponding idioms that are available in the $T L$ :

(6) I dabogda trag nam se zatro, kad pod ovom živjeli maramom! (TMW: 303) / May God leave no trace of us, When we live with kerchieves on our head. (Mrkić: 303) May God remove all the trace of our race if we should live in cowardice and disgrace! (Mihailović: 341 ) / Of our lov'd race may God remove all trace, If we should live in cowardice and disgrace! (Wiles:340)

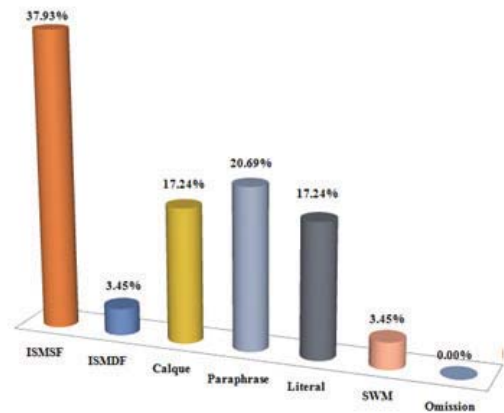

Figure 1. Distribution of translation strategies within the category of pure idioms

\subsection{Idiomatic similes}

Similes were successfully translated into TL despite the fact that some available idiomatic equivalents were not used. Rather than being focused on idiomatic pairs, translators were seeking semantic equivalence. The choice of translation strategies within the dichotomy universal/culture specific IE remains almost the same as it was within the category of pure idioms. The sole example of "universal" simile sladak kao cukar was rendered into TL as idiom (sweet as sugar). Culturespecific similes were generally translated word-for-word (calquing) (5), yet there are examples of literal translation as well (6):

(7) I ja plačem ka malo dijete. (1301: TMW)/ and I, too, was weeping like an infant. (Mihailović:1341)/ I wept - shed tears just like a child. (Wiles: 1361)/ And I too wept like a little child. (Mrkić: 1301)

(8) ka pjan plota kada se prihvati. (TMW: 2379)/ As a drunk holds onto the railing. (Mrkić: 2379)/ like a drunk man holding onto the fence. (Mihailović: 2479)/ As men in cups do hold the hedge along. (Wiles: 2498).

\footnotetext{
${ }^{1}$ The expression in the SL, literally translated as "the fierce dragon" actually refers to a person of exceptional courage

2 The expression since Kosovo has a double meaning : literal (since the battle of Kosovo of 1389) and idiomatic meaning : (equivalent to English expression since time immemorial) and it is used in the text in both senses at the same time.
} 


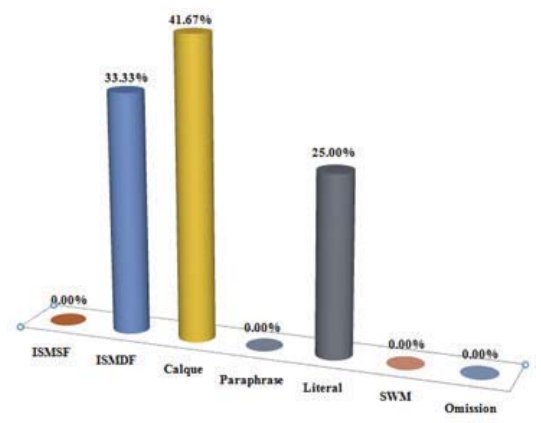

Figure 2. Distribution of translation strategies within the category of idiomatic similes

\subsection{Proverbs and sayings}

Unlike the two previous categories where cultural markedness and/or semantic opacity were major factors contributing to the choice of strategies, proverbs and sayings illustrate the influence authorial modifications of conventional idioms may have on the process of translation.

Given that idiomatic pairs exist for each of the proverbs and sayings analyzed, we draw conclusion that it was precisely unsuccessful interpretation of IE in the SL that determined the choice of strategies. In other words, when faced with IE that appear in the form that is not "institutionalized "(found in the dictionaries) translators might have some problems to understand and subsequently translate them. Except for the case of literal translation of the proverb vrana vrani oči ne izvadi (Enlish equivalent hawk will not pluck hawks' eyes) other IE were mainly transferred into TL as calques:

(9) na muci se poznaju junacil3(TMW: 136) / In adversity you recognize the heroes (Mrkić: 137) / adversity shows who is the hero (Mihailović: 175) / Adversity is e'er the hero's school! (Wiles: 170).

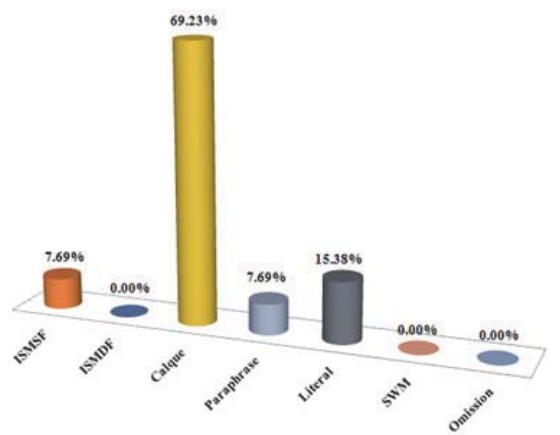

Figure 3. Distribution of translation strategies within the category of proverbs and sayings

\subsection{Locutions}

Given that the analyzed examples of locutions don't fall into a category of language and culture specific expressions, the prevalence of idiom-to-idiom translation strategies was expected. Results of the analysis show that there is no significant difference between observed and expected prevalence: locutions were mainly rendered into TL as idioms (God willing, Dear Lord, etc.) with only a few cases of calques and paraphrased expressions. There is, however, a case of translation by omission:

(10) Ne boj mi se, ako Bog da, đedo! (TMW: 2538)/ Grandsire, fear not for me, by God's good will! (Wiles: 2675)/ Fear

${ }^{3}$ Idiomatic pair in English: Adversity is the touchstone of virtue. 
not for me, by God's good will, granddad! (Mihailović: 2642)/ Do not fear for me, old father (Mrkić: 2538).

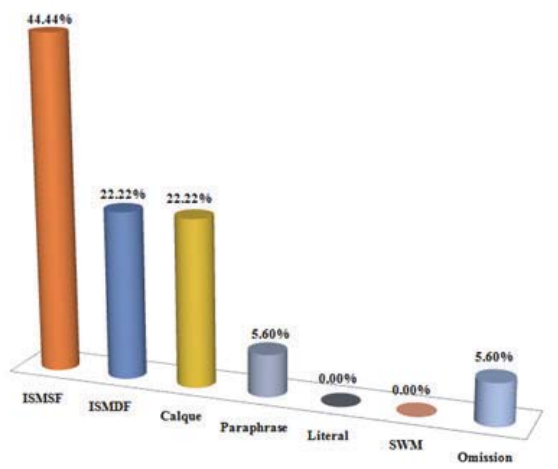

Figure 4. Distribution of translation strategies within the category of locutions

\section{Conclusion}

The present research was an attempt to examine idiom translation strategies in English translations of the poem "The Mountain Wreath". The primary focus was on determining the impact that cultural markedness of IE makes on the choice of translation strategies. The analysis performed led to the following conclusions:

- the major factors contributing to the choice of strategies were cultural markedness, semantic opacity and the use of authorial modifications of IE.

- $\quad$ the translators wanted to keep as close as possible to the original text, so loan translation (calque) appears to be the prevalent strategy when it comes to culture-specific IE.

- IE of universal character were mainly translated by using one of the two idiom-to-idiom translation strategies.

- loan translation and single word matches/translation by omission were the most and the least common strategies overall, with the frequencies of $31.94 \%$ and $1.39 \%$, respectively.

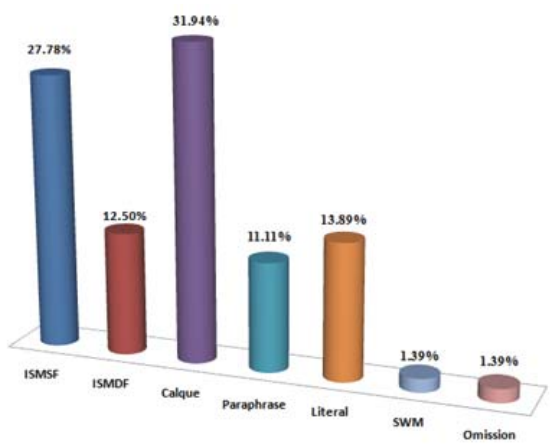

Figure 5. Distribution of idiom translation strategies in the poem "The Mountain Wreath" 


\section{References}

Awwad, M. (1990). Equivalence and translatability of English and Arabic idioms. u: Papers and Studies in Contrastive Linguistics 26, 5767. Poznan, Adam Mickiewicz University.

Baker, M. (1992). In other words: A coursebook on translation. London and New York: Routledge.

Banašević, N. (1978). Gorski vijenac. Kritičko izdanje s komentarom priredio Nikola Banašević. Drugo izdanje. Beograd: Srpska književna zadruga.

Bassnet, S. (1991). Translation studies London and New York: Routledge, Taylor and Francis Group.

Casas-Monroy R. and Hernandez-Campoy (1995). J.M..A Sociolinguistic Approach to the Study of Idioms: Some Anthropolinguistic Sketches. Cuadernos de Filología Inglesa 4: 43-61.

Cowie, A. P., Mackin, R. (1975). Oxford Dictionary of Current Idiomatic English. Oxford : Oxford University Press.

Cowie, A. (1998). Phraseology: Theory, Analysis, and Applications, Oxford, Clarendon Press.

Everaert, M. et al. (Eds) (1995). Idioms: Structural and Psychological Perspectives. Hillsdale: Lawrence Erlbaum Associates Publishers.

Fernando, C. (1996). Idioms and Idiomacity. Oxford: Oxford University Press.

Gläser, R. (1984). The Translation Aspect of Phraseological Units in English and German. Papers and Studies in Contrastive Linguistics 18: 123-134, Poznan, Adam Mickiewicz University.

Gries, Th. S. Phraseology and linguistic theory: A brief survey in Granger, S. and Meunier F. (eds.) (2008). Phraseology: An interdisciplinary perspective. Amsterdam: John Benjamins Publishing Company.

Healey, A. (1968). English Idioms. Kivung, Vol. No.2. 71-108. Papua New Guinea.

Kovačević, Ž. (2002). Srpsko-engleski frazeološki rečnik. Beograd: Filip Višnjić.

Kövecses, Z. (2006). Language, Mind, and Culture. Oxford: Oxford University Press.

Kržišnik, E., Eismann, W. (2007). Phraseology in linguistics and other branches of science. Ljubljana: Univerza v Ljubljani.

Makkai, A. (1972). Idiom structure in English. Hague/Paris: Mouton.

Matešić, J. (1982). Frazeološki rječnik hrvatskoga ili srpskoga jezika. Zagreb: Školska knjiga

McMordie, W. (1972). English Idioms and how to use them. London: Oxford University Press.

Mihailović, D. V. (1997). The Mountain Wreath. Beograd: Serbian Europe.

Milosavljević, B. (2007). Srpsko-engleski rečnik idioma. Beograd: Zavod za udžbenike.

Mrkić, D. (1985). Mountain Laurel. Ottawa: Commoners' Publishing.

Pejanović, A. (2010). Frazeologija Gorskog vijenca. Podgorica: CANU.

Ratcliffe, S. ed. (2002). The Oxford Dictionary of Phrase, Saying and Quotation. Oxford: Oxford University Press.

Schwarz, Barbara (2002-3). "Translation in a Confined Space", part 1 in Translation Journal, Vol. 6, No. 4, Oct. 2002, part 2 in Vol. 7 , No.1, Jan. 2003. Available at http://www.accurapid.com/journal/22 subtitles.htm and http://www.accurapid.com/journal/23 subtitles.htm

Speake J. ed. (1998). The Oxford dictionary of idioms. Oxford: Oxford University Press.

Strässler, J. (1982). Idioms in English: A pragmatic analysis. Tübingen: Günter Narr.

Toby, J. ed. (2001). Oxford idioms dictionary for learners of English. Oxford: Oxford University Press.

Valero-Garcés, C. (1997). Contrastive idiomatology and translatability of English and Spanish idioms. Papers and Studies in Contrastive Linguistics 32, 29-38. Poznan: Adam Mickiewicz University.

Wiles, W. James (1930). The Mountain Wreath. London: George Allen \& Unwin, Ltd. 